\title{
Chapter 2. The Interpretation and Development of International Human Rights Law by the International Court of Justice
}

Gentian Zyberi*

\section{Introduction}

The International Court of Justice (ICJ or Court) is one of the main organs ${ }^{1}$ of the United Nations (UN) and its principal judicial organ. ${ }^{2}$ Certain institutional features, such as being a court of general jurisdiction entrusted with both a contentious and an advisory function, its important place within the UN system and its membership composed of independent judges representing the principal legal systems of the world, make the Court well situated for integrating international human rights law rules and principles into the broader corpus of public international law. This chapter will analyse the contribution of the ICJ to interpreting and developing some important rules and principles of international human rights law aimed at ensuring a basic protection of individuals under international law. First, the chapter puts into perspective the place of the ICJ within the larger framework of international adjudication and enforcement of human rights norms. Then, the chapter turns to the institutional possibilities and limitations of the Court in engaging in the process of interpreting and developing human rights norms, discussing both advisory proceedings and contentious cases. The analysis addresses all three procedural stages in contentious cases, namely preliminary objections, merits and reparations. Third, the chapter analyses the contribution of the Court to clarifying procedural, substantive and institutional issues concerning the understanding and implementation of key human rights norms. In analysing the case law of the Court, it is important to distinguish between cases involving bilateral disputes with human rights aspects and cases involving matters of general concern for the international community as a whole (section 4.1.3 below). Finally, the chapter provides some concluding remarks.

An institutional approach is used in discussing the role of the ICJ within the context of international adjudication and enforcement of human rights, as well as its contribution to the interpretation and development of key human rights rules and principles. The institutional possibilities and limitations of the Court are highlighted in order to understand the legal and political confines within which the Court operates. Notably, the Court's contribution has been explained from three angles: a procedural, a substantial and an institutional angle. Obviously, the ICJ can interpret and develop the law, but it is for States, international and regional organisations and individuals to comply with their legal obligations. The existence and activity of the Court can help to reinforce the rule of law and the values embedded in human rights norms.

\section{The Place of the ICJ among other International Adjudication Mechanisms}

There are three facts that must be stated upfront at the beginning of this section. First, the field of international adjudication mechanisms has changed radically from 1945, when the UN Charter established the ICJ as one of the then very few international courts, to currently when

\footnotetext{
* Professor of International Law and Human Rights, Norwegian Centre for Human Rights, University of Oslo. Member of the Permanent Court of Arbitration. In writing this chapter, I have drawn heavily from my previous work on the International Court of Justice. Comments are welcome at gentian.zyberi@nchr.uio.no. All the Court's decisions are available on its website, at www.icj-cij.org.

${ }^{1}$ UN Charter, Article 7(1).

${ }^{2}$ UN Charter, Article 92.
} 
the ICJ operates alongside many international courts and quasi-judicial mechanisms. ${ }^{3}$ Reflecting upon this change, Kingsbury has pointed out no less than ten types of international adjudicatory mechanisms. ${ }^{4}$ Second, despite the lapse of time and the establishment of many international adjudication mechanisms, no hierarchical relationship has been established among them. Third, the ICJ enjoys a somewhat special position as first among equals, mainly based on the Court being one of the main UN organs and its principal judicial organ. ${ }^{5}$ This special position of the Court, especially when it comes to its findings on general public international law, is reflected to some extent in the fact that many adjudicatory mechanisms have cited with approval the ICJ's legal findings. The Court is an international court of general jurisdiction, and of universal reach when it comes to membership, since all UN member States are ipso facto parties to the Statute of the Court, which is annexed to the UN Charter. Moreover, even nonUN member States can get access to the Court. In terms of the potential reach of the Court's jurisdiction, five of the nine main UN human rights treaties include a compromissory clause vesting the ICJ with jurisdiction in case disputes would arise among States about the interpretation or the application of said treaty. ${ }^{6}$ While initially there was a certain fear of fragmentation of international law and potential for contradicting legal findings by international courts, ${ }^{7}$ the general interaction of the ICJ with other international courts and quasi-judicial bodies has been constructive and cordial, with minor exceptions. ${ }^{8}$ However, the potential for fragmentation and potentially conflicting interpretations remains, as occasionally States or individuals have submitted the same disputes to the ICJ and to another court, especially the European and the Inter-American regional human rights courts. ${ }^{9}$ Shany has analysed a number

\footnotetext{
${ }^{3}$ See inter alia C. Romano, K. Alter and Y. Shany (eds.), The Oxford Handbook of International Adjudication (Oxford: Oxford University Press, 2014).

4 B. Kingsbury, 'International Courts: Uneven Judicialisation in Global Order', in J. Crawford and M.
} Koskenniemi (eds.), The Cambridge Companion to International Law (Cambridge: Cambridge University Press, 2012), pp. 205-11.

${ }^{5}$ See K. Oellers-Frahm, 'Article 92 UN Charter', in A. Zimmermann et al. (eds.), The Statute of the International Court of Justice: A Commentary ( $2^{\text {nd }}$ edn, Oxford: Oxford University Press, 2012), pp. 171-7. For a view putting the ICJ at the apex see among others C. Leathley, 'An Institutional Hierarchy to Combat the Fragmentation of International Law: Has the ILC Missed an Opportunity?', New York University Journal of International Law and Politics, 40 (2007), 259-306. For a more critical assessment see H. Thirlway, 'The International Court of Justice 1989-2009: At the Heart of the Dispute Settlement System?', Netherlands International Law Review, 57 (2010), 347-95.

${ }^{6}$ See section 3.1 below.

7 Report of the Study Group of the International Law Commission, Fragmentation of International Law: Difficulties Arising from the Diversification and Expansion of International Law (Finalized by Martti Koskenniemi), UN Doc. A/CN.4/L.682, 13 April 2006, paras. 49-52.

${ }^{8}$ See Prosecutor v. Tadić, ICTY Case No. IT-94-1-A, Judgment, 15 July 1999, paras. 99 et seq. and compare it with Case Concerning Application of the Convention on the Prevention and Punishment of the Crime of Genocide (Bosnia and Herzegovina v. Serbia and Montenegro), ICJ Reports (2007) 43, paras. 402 et seq. (the Genocide case I).

${ }^{9}$ Some examples include Mexico submitting a request for an advisory opinion by the Inter-American Court of Human Rights (IACtHR) on The Right to Information on Consular Assistance in the Framework of the Guarantees of the Due Process of Law, Advisory Opinion OC-16/99, 1 October 1999, Ser. A, No. 16, and a contentious case before the ICJ in 2003 concerning Mexican nationals in the death row in the United States of America (USA) (Case Concerning Avena and Other Mexican Nationals (Mexico v. United States of America), ICJ Reports (2004) 12; the Case of Prince Hans-Adam II of Liechtenstein v. Germany (Appl. No. 42527/98), Judgment (Grand Chamber), 12 July 2001, ECHR 2001-VIII, submitted before the European Court on Human Rights (ECtHR) and Certain Property (Liechtenstein v. Germany), ICJ Reports (2005) 6) submitted before the ICJ, both concerning property rights; Georgia submitting a case before the ICJ (Case Concerning Application of the International Convention on the Elimination of All Forms of Racial Discrimination (Georgia v. Russian Federation), ICJ Reports (2011) 70) (the Georgia case) and before the ECtHR (Georgia v. Russia (I) (Appl. No. 13255/07), Judgment (Grand Chamber), 3 July 2014 and Georgia v. Russia (II) (Appl. No. 38263/08), pending before the Grand Chamber), concerning the August 2008 armed conflict with the Russian Federation; and Ukraine submitting a case before the ICJ (Case Concerning the Application of the International Convention for the Suppression of the 
of problems, which might arise in this context. ${ }^{10}$ An important concern is that of conflicting interpretations of legal norms and concepts by different international courts, which could create problems for the systematic coherence and unity of international law. However, so far, such fears have proven exaggerated.

\section{Practice-Related Problems Concerning Enforcement of Human Rights through the ICJ}

Significant scholarly attention has been devoted to the Court's contribution to developing international law, ${ }^{11}$ as well as to interpreting and developing international human rights law. ${ }^{12}$ The Court's use of the sources of international law, especially customary international law, has been subject to some criticism. ${ }^{13}$ The Court is open to States through its contentious jurisdiction, as well as to the main organs of the UN and the UN specialised agencies through its advisory jurisdiction. Being a court of general jurisdiction and having both contentious and advisory jurisdiction, the Court is well placed to play an important role in interpreting and developing human rights. Besides its normative contribution (see section 4.2 below), the Court has also

Financing of Terrorism and of the International Convention on the Elimination of All Forms of Racial Discrimination (Ukraine v. Russian Federation), pending) (the Ukraine case) and before the European Court on Human Rights (Ukraine v. Russia (Appl. No. 20958/14), Ukraine v. Russia (IV) (Appl. No. 42410/15), Ukraine v. Russia (V) (Appl. No. 8019/16), Ukraine v. Russia (VI) (Appl. No. 70856/16), all pending before the Grand Chamber), concerning human rights violations in the context of the occupation of Crimea by the Russian Federation and the armed conflict in Eastern Ukraine.

${ }^{10}$ See generally Y. Shany, The Competing Jurisdictions of International Courts and Tribunals (Oxford: Oxford University Press, 2003).

${ }^{11}$ See inter alia $\mathrm{H}$. Lauterpacht, The Development of International Law by the International Court (London: Steven \& Sons Limited, 1958); C. J. Tams and J. Sloan (eds.), The Development of International Law by the International Court of Justice (Oxford: Oxford University Press, 2013); N. Boschiero et al. (eds.), International Courts and the Development of International Law: Essays in Honour of Tullio Treves (The Hague: T. M. C. Asser Press, 2013).

${ }^{12}$ See generally G. Zyberi, The Humanitarian Face of the International Court of Justice: Its Contribution to Interpreting and Developing International Human Rights and Humanitarian Law Rules and Principles (Antwerp and Portland, Oregon: Intersentia, 2008); B. Simma 'Human Rights before the International Court of Justice: Community Interest Coming to Life?', in Tams and Sloan, 'Development of International Law', pp. 301-25. See also N. S. Rodley, 'Human Rights and Humanitarian Intervention: The Case Law of the World Court', International and Comparative Law Quarterly, 38 (1989), 321-33; R. Goy, La Cour Internationale de Justice et les Droits de l'Homme (Brussels: Bruylant/ Nemesis, 2002); S. R. S. Bedi, The Development of Human Rights Law by the Judges of the International Court of Justice (Oxford and Portland, Oregon: Hart Publishing, 2007); R. Higgins, 'Human Rights in the International Court of Justice', Leiden Journal of International Law, 20 (2007), 745-51; S. Sivakumaran, 'The International Court of Justice and Human Rights', in S. Joseph and A. McBeth (eds.), Research Handbook on International Human Rights Law (Cheltenham: Edward Elgar, 2010), pp. 299-325; G. Zyberi 'Human Rights in the International Court of Justice', in M. Baderin and M. Ssenyonjo (eds.), International Human Rights Law: Six Decades Years after the UDHR and Beyond (Farnham: Ashgate, 2010), pp. 289-304; R. Wilde, 'Human Rights beyond Borders at the World Court: The Significance of the International Court of Justice's Jurisprudence on the Extraterritorial Application of International Human Rights Law Treaties', Chinese Journal of International Law, 12 (2013), 639-77; G. Zyberi, 'The International Court of Justice and the Rights of Peoples and Minorities', in Tams and Sloan, 'Development of International Law', pp. 327-52; N. Rodley, 'The International Court of Justice and Human Rights Treaty Bodies', in J. A. Green and C. P. M. Waters (eds.), Adjudicating International Human Rights: Essays in Honour of Sandy Ghandhi (Leiden: Brill Nijhoff, 2015), pp. 12-33; International Law Association, International Human Rights Committee, Washington Conference (2014), Interim Report 'International Human Rights Law and the International Court of Justice (ICJ)', available at: www.ila-hq.org/index.php/committees.

${ }^{13}$ See inter alia S. Talmon, 'Determining Customary International Law: The ICJ's Methodology between Induction, Deduction and Assertion', European Journal of International Law, 26 (2015), 417-43; S. Yee, 'Article 38 of the ICJ Statute and Applicable Law: Selected Issues in Recent Cases', Journal of International Dispute Settlement, 7 (2016), 472-98; N. Petersen, 'The International Court of Justice and the Judicial Politics of Identifying Customary International Law’, European Journal of International Law, 28 (2017), 357-85. 
furthered the justiciability of human rights. ${ }^{14}$ While the Court's contribution has been important, several cases have highlighted the jurisdictional gaps and other obstacles to litigating human rights cases before the Court. These cases have also highlighted the Court's guarded position on certain controversial issues under international law, especially that of State and State officials' immunity before foreign domestic courts for serious human rights violations.

There are three stages of litigation before the ICJ for contentious cases, namely the preliminary objections stage, the merits stage and the reparations stage. Each of these stages has been important in clarifying different aspects of the enforcement of international human rights, from jurisdictional issues, to the law of international responsibility for serious violations of human rights, to principles concerning reparations due to those affected from such violations. Besides, in contentious cases there is also the possibility of incidental proceedings concerning the indication of provisional measures. This procedure has been quite important for human rights in diplomatic protection or consular relations cases, ${ }^{15}$ as well as in several cases concerning armed conflict situations. ${ }^{16}$ While the process of monitoring and ensuring State compliance with these orders of the Court needs further development, the binding nature of such orders was firmly established by the Court in the LaGrand case in $2001 .{ }^{17}$ Failure to comply with a provisional measures order triggers State responsibility.

\subsection{The Preliminary Objections Stage}

The preliminary objections stage at the ICJ has exposed both the jurisdictional limitations and gaps that exist in international human rights treaties, as well as a general reluctance by States to bring or argue cases before the Court based primarily on human rights grounds. In terms of ICJ's jurisdictional limitations, two issues must be noted beforehand. First, only 73 of the 193 UN member States have accepted the compulsory jurisdiction of the ICJ under Article 36(2) of its Statute. ${ }^{18}$ Second, as mentioned above, only five out of the nine main human rights treaties include a compromissory clause, namely the treaties focusing on elimination of racial

\footnotetext{
${ }^{14}$ See among others J. Grimheden, 'The International Court of Justice in Furthering the Justiciability of Human Rights', in G. Alfredsson et al. (eds.), International Human Rights Monitoring Mechanisms: Essays in Honour of Jakob Th. Möller (The Hague: Kluwer Law International, 2001), pp. 469-84.

${ }^{15}$ Cases concerning consular protection are Case Concerning the Vienna Convention on Consular Relations (Paraguay v. United States of America), ICJ Reports (1998) 248 (the Breard case); LaGrand Case (Germany v. United States of America), ICJ Reports (1999) 9; Case Concerning Avena and Other Mexican Nationals (Mexico v. United States of America), ICJ Reports (2003) 77; and Jadhav (India v. Pakistan), ICJ Reports (2017) 231. Two recent cases concerning diplomatic protection are Immunities and Criminal Proceedings (Equatorial Guinea $v$. France), ICJ Reports (2016) 1148; and Application of the International Convention on the Elimination of All Forms of Racial Discrimination (Qatar v. United Arab Emirates), available at: www.icj-cij.org/en/case/172.

${ }^{16}$ See Case Concerning Application of the Convention on the Prevention and Punishment of the Crime of Genocide (Bosnia and Herzegovina v. Serbia and Montenegro), ICJ Reports (1993) 3; Case Concerning Legality of Use of Force (Yugoslavia v. Spain), ICJ Reports (1999) 761; Case Concerning Armed Activities on the Territory of the Congo (Democratic Republic of the Congo v. Uganda), ICJ Reports (2000) 111; Application of the International Convention on the Elimination of all Forms of Racial Discrimination (Georgia v. Russian Federation), ICJ Reports (2008) 353; Application of the International Convention for the Suppression of the Financing of Terrorism and of the International Convention on the Elimination of All Forms of Racial Discrimination (Ukraine v. Russian Federation), ICJ Reports (2017) 104. See generally G. Zyberi, 'Provisional Measures of the International Court of Justice in Armed Conflict Situations', Leiden Journal of International Law, 23 (2010), 571-84.

${ }^{17}$ LaGrand Case (Germany v. United States of America), ICJ Reports (2001) 466, para. 128(5).

${ }^{18}$ Statute of the International Court of Justice, San Francisco, 26 June 1945, in force 24 October 1945, 3 Bevans 1179; 59 Stat. 1031; T.S. 993; 39 AJIL Supp. 215 (1945), Article 36(2).
} 
discrimination, ${ }^{19}$ elimination of discrimination against women, ${ }^{20}$ on prevention and punishment of torture, ${ }^{21}$ on the protection of the rights of migrant workers and their families, ${ }^{22}$ and on the elimination of enforced disappearances. ${ }^{23}$ Notably, neither of the two international covenants contains a compromissory clause. ${ }^{24}$ These jurisdictional gaps and limitations have caused States to stretch the Court's jurisdictional basis under the Convention on the Prevention and Punishment of the Crime of Genocide (Genocide Convention) $)^{25}$ or the CERD to bring cases involving serious human rights or humanitarian law violations.

The fact that there are three types of compromissory clauses further complicates the process of seising the Court. The first type allows a State to seise the ICJ without a need to exhaust any other remedies. ${ }^{26}$ The second type requires a party to the dispute to resort to negotiation before seising the Court. ${ }^{27}$ The third type requires a more structured sequencing, whereby negotiation is placed first, then a request for arbitration by one of the parties and if, after six months, the parties are unable to agree on the organisation of arbitration, then either of them can resort to the Court. ${ }^{28}$ A cursory look at the evolution of compromissory clauses reveals that over time the process of seising the Court has become more complex and difficult. This leads to both positive and negative consequences. The positive consequence is that States are first required to negotiate and try to solve their disputes before seising the Court and unnecessarily increase its caseload. The negative consequence is that the protection of human rights can become subject to foot-dragging and prolonged State negotiations through diplomatic channels, while potentially serious human rights violations could go unaddressed for several months or even years.

\subsection{The Merits Stage}

\footnotetext{
${ }^{19}$ International Convention on the Elimination of All Forms of Racial Discrimination (CERD), New York, 21 December 1965, in force 4 January 1969, UNGA Res. 2106 (XX), Annex, 20 U.N. GAOR Supp. (No. 14) at 47, UN Doc. A/6014 (1966); 660 UNTS 195, Article 22.

${ }^{20}$ Convention on the Elimination of All Forms of Discrimination against Women (CEDAW), New York, 18 December 1979, in force 3 September 1981, UNGA Res. 34/180, 34 UN GAOR Supp. (No. 46) at 193, UN Doc. A/34/46; 1249 UNTS 13, Article 29.

${ }^{21}$ Convention against Torture and Other Cruel, Inhuman or Degrading Treatment or Punishment (CAT), New York, 10 December 1984, in force 26 June 1987, UNGA Res. 39/46, Annex, 39 UN GAOR Supp. (No. 51) at 197, UN Doc. A/39/51 (1984); 1465 UNTS 85, Article 30.

${ }^{22}$ International Convention on the Protection of the Rights of All Migrant Workers and Members of Their Families (CMW), New York, 18 December 1990, in force 1 July 2003, GA Res. 45/158, Annex, 45 U.N. GAOR Supp. (No. 49A) at 262, UN Doc. A/45/49 (1990); 2220 UNTS 3, Article 92.

${ }^{23}$ International Convention for the Protection of All Persons from Enforced Disappearance (CPED), New York, 20 December 2006, in force 23 December 2010, UNGA Res. 61/177, Annex; 2716 UNTS 3, Article 42.

${ }^{24}$ See International Covenant on Civil and Political Rights (ICCPR), New York, 16 December 1966, in force 23 March 1976, GA Res. 2200A (XXI), 21 UN GAOR Supp. (No. 16) at 52, UN Doc. A/6316 (1966); 999 UNTS 171; International Covenant on Economic, Social and Cultural Rights, New York, 16 December 1966, in force 3 January 1976, GA Res. 2200A (XXI), 21 UN GAOR Supp. (No. 16) at 49, UN Doc. A/6316 (1966); 993 UNTS 3.

${ }^{25}$ Genocide Convention, Paris, 9 December 1948, in force 12 January 1951, 78 UNTS 277.

${ }^{26}$ Genocide Convention, Article IX: '[D]isputes [...] relating to the interpretation, application or fulfilment of the present Convention, including those relating to the responsibility of a State for genocide or for any of the other acts enumerated in article III, shall be submitted to the International Court of Justice at the request of any of the parties to the dispute.'

${ }^{27}$ CERD, Article 22: 'Any dispute [...] with respect to the interpretation or application of this Convention, which is not settled by negotiation or by the procedures expressly provided for in this Convention, shall, at the request of any of the parties to the dispute, be referred to the International Court of Justice for decision, unless the disputants agree to another mode of settlement.'. See the Georgia case; the Ukraine case.

${ }^{28}$ CEDAW, Article 29; CAT, Article 30; CMW, Article 92; CPED, Article 42.
} 
This is the main stage of the proceedings before the ICJ and relevant for clarifying aspects of State responsibility for human rights violations, through acts or omissions of State organs or persons whose acts engage its responsibility. ${ }^{29}$ In several cases, the Court has held States in violation of their human rights obligations, including for unlawfully expelling a person from their territory; ${ }^{30}$ inadequate conditions of arrest and detention; ${ }^{31}$ unlawful destruction and requisition of property; ${ }^{32}$ impediments to the exercise of the right to work, to health, to education and to an adequate standard of living; ${ }^{33}$ failure to fully cooperate with the International Criminal Tribunal for the former Yugoslavia (ICTY) ${ }^{34}$ failure to investigate and prosecute serious violations of human rights; ${ }^{35}$ failure to prevent genocide $;{ }^{36}$ failure to respect the peoples' right to self-determination ${ }^{37}$ and so on. Notably, carrying the burden of proof could be quite demanding in cases concerning serious human rights violations. However, in more recent years, the Court has had resort to reports and other materials prepared by UN entities, including by UN peacekeeping missions.

\subsection{The Reparations Stage}

This is the final stage of the proceedings where the issue of reparations for violations is settled by the Court, based on the parties' submissions. Thus far, the Court has indicated reparations in three cases, namely the Corfu Channel case ${ }^{38}$ the Wall case ${ }^{39}$ and the Diallo case. ${ }^{40}$ Overall, it is possible to distinguish an evolution in the position of the Court over time, leading to an increased focus on the rights of the affected individuals instead of on those of the State exercising diplomatic protection. In the Corfu Channel case, among others the Court ordered compensation from Albania to the United Kingdom for deaths and injuries of British naval personnel in Albanian territorial waters. ${ }^{41}$ In the Wall case, the ICJ indicated Israel's 'obligation to make reparation for all damage caused by the construction of the wall in the Occupied Palestinian Territory, including in and around East Jerusalem'. ${ }^{42}$ Importantly, the Court found that 'given that the construction of the wall in the Occupied Palestinian Territory had, inter alia, entailed the requisition and destruction of homes, businesses and agricultural holdings', Israel had 'the obligation to make reparation for the damage caused to all the natural or legal persons

\footnotetext{
${ }^{29}$ See among others Legal Consequences of the Construction of a Wall in the Occupied Palestinian Territory, ICJ Reports (2004) 136; the Genocide case I; Application of the Convention on the Prevention and Punishment of the Crime of Genocide (Croatia v. Serbia), ICJ Reports (2015) 3 (the Genocide case II); Case Concerning Armed Activities on the Territory of the Congo (Democratic Republic of the Congo v. Uganda), ICJ Reports (2005) 168; Questions relating to the Obligation to Prosecute or Extradite (Belgium v. Senegal), ICJ Reports (2012) 422; Jurisdictional Immunities of the State (Germany v. Italy: Greece Intervening), ICJ Reports (2012) 99.

${ }^{30}$ Case Concerning Ahmadou Sadio Diallo (Republic of Guinea v. Democratic Republic of the Congo), ICJ Reports (2010) 639, para. 165(2).

${ }^{31}$ Ibid., para. 165(3).

${ }^{32}$ Wall, paras. 132, 152.

${ }^{33}$ Ibid., para. 134.

34 The Genocide case I, para. 471(6).

${ }^{35}$ Obligation to Prosecute or Extradite, paras. 119-22, especially paras. 120 and 122(4), (5) and (6).

36 The Genocide case I, para. 471(5).

${ }^{37}$ Wall, paras. $155,159$.

${ }^{38}$ Corfu Channel Case (United Kingdom of Great Britain and Northern Ireland v. Albania), Assessment of the amount of compensation due from the People's Republic of Albania to the United Kingdom of Great Britain and Northern Ireland, ICJ Reports (1949) 244.

${ }^{39}$ Wall, paras. $151,152,163(3)(\mathrm{C})$.

${ }^{40}$ Case Concerning Ahmadou Sadio Diallo (Republic of Guinea v. Democratic Republic of the Congo), ICJ Reports (2012) 324.

${ }^{41}$ Corfu Channel, ICJ Reps 1949, pp. 249-50.

${ }^{42}$ Wall, para. $163(3)(C)$.
} 
concerned' ${ }^{43}$ This was the first time when the Court indicated an obligation for reparations directly to the natural and legal persons affected by international law violations. In the Diallo case, the Court ordered compensation for both the material and non-material injury suffered by Mr Diallo. ${ }^{44}$ Importantly, the Court recalled that 'the sum awarded to Guinea in the exercise of diplomatic protection of Mr. Diallo is intended to provide reparation for the latter's injury'. ${ }^{45}$ However, the Court also found that 'no compensation is due by the Democratic Republic of the Congo to Guinea [...] for a loss of professional remuneration during [Mr Diallo's] unlawful detentions and following his unlawful expulsion', ${ }^{46}$ nor 'as a result of a deprivation of potential earnings'. ${ }^{47}$ A controversial case, where the ICJ took a strict approach to reparations, is the Application of the Genocide Convention. In this case, the Court established a test requiring 'a sufficiently direct and certain causal nexus between the wrongful act, [namely] [a State's] breach of the obligation to prevent genocide, and the injury suffered by the [injured State], consisting of all damage of any type, material or moral, caused by the acts of genocide'. ${ }^{48}$ Since the causal nexus was not found proven in this case, the Court decided that 'financial compensation is not the appropriate form of reparation for the breach of the obligation to prevent genocide'. ${ }^{49}$ This approach of the Court to reparations for mass atrocity crimes has been subject to criticism. ${ }^{50}$ Also, in the Jurisdictional Immunities of the State, the Court dismissed the Italian counter-claim concerning the right to a remedy for lack of ratione temporis jurisdiction. In this case, the ICJ upheld State immunity before foreign domestic courts, even though this practically meant denying the right to a remedy to victims of serious international humanitarian law violations by Nazi Germany during World War II, including murder, deportation and slave labour.

\section{The Engagement of the ICJ with Fundamental International Human Rights Rules and Principles}

Despite the fact that the ICJ is not a human rights court, over time it has dealt with several cases concerning fundamental international human rights rules and principles. Some of these issues relate to elements of international public order within the international legal system, especially State obligations under the Genocide Convention or the evolution of the concept of jus cogens and of obligations erga omnes in international law. ${ }^{51}$ The development of international human rights law can be described as consisting of three phases, namely the first phase including standard-setting from 1948 to 1966 with the adoption of the Universal Declaration of Human Rights (UDHR), the CERD and the two international covenants, the second phase including the development of enforcement mechanisms and procedures through the State reporting and the individual communications procedures and the third phase involving mainstreaming of human rights in all the work of the UN. In terms of the standard-setting process, since the CPED and

\footnotetext{
${ }^{43}$ Ibid., para. 152.

${ }^{44}$ Diallo (2012), paras. 61(1), 61(2). The non-material injury was fixed at US\$85,000 and the material injury suffered by Mr. Diallo in relation to his personal property at US\$10,000.

45 Ibid., para. 57.

46 Ibid., para. 61(3).

${ }^{47}$ Ibid., para. 61(4).

48 The Genocide case I, para. 462.

${ }^{49}$ Ibid.

50 See inter alia C. McCarthy, 'Reparation for Gross Violations of Human Rights Law and International Humanitarian Law at the International Court of Justice', in C. Ferstman, M. Goetz and A. Stephens (eds.), Reparations for Victims of Genocide, War Crimes and Crimes against Humanity: Systems in Place and Systems in the Making (Leiden: Martinus Nijhoff Publishers, 2009), pp. 283-311.

${ }^{51}$ See inter alia H. Owada, 'The Changing Docket of the International Court of Justice and the Significance of the Change Going Forward', Proceedings of the Annual Meeting (American Society of International Law), 103 (2009), 400-1.
} 
the Convention on the Rights of Persons with Disabilities (CRPD), ${ }^{52}$ both of 2006, no other major international human rights treaty has been adopted. ${ }^{53}$ In terms of the human rights enforcement, the UN has started a process for improving the monitoring and enforcement of human rights by the UN treaty bodies. In terms of the process of mainstreaming, human rightsbased approaches and the gender equality dimension permeate the work of different UN entities.

The engagement of the ICJ with human rights can also be separated into different phases. Simma has distinguished two such phases, the first one of hesitation and restraint and the second one where the Court engages more fully with human rights. ${ }^{54}$ If one were to adopt a combination of a chronological and a topical (substantive) approach, then we can distinguish three phases in the engagement of the ICJ with human rights. There is an early phase lasting until the late 1970s, where the Court supports the process of the internationalisation of human rights and the monitoring function of the UN. The Court does this by reference to general principles of international law, such as elementary considerations of humanity, the prohibition of slavery and of racial discrimination, or by drawing support from the general human rights provisions of the UDHR and the UN Charter. There is a second phase of about 15-20 years, stretching from the late 1970s until after the end of the Cold War, where the Court occasionally and somewhat reluctantly engages with human rights issues, cautiously avoiding being dragged into the ideological divide between the Eastern and the Western bloc. Finally, we can distinguish a third phase from the 1990s onwards, where international human rights law is fairly well-established, as is the Court's reputation. Consequently, States have brought cases involving human rights violations more frequently and the Court has engaged quite closely with different human rights issues.

The contribution of the Court to interpreting and developing human rights law can be seen from three related angles, a procedural angle, a normative angle and an institutional angle. The procedural angle has to do with access to the Court and the justiciability of human rights violations. This is quite closely related to the Statute and the Rules of Court and the extent to which States can use international human rights law sources in bringing cases and construing arguments before the Court. The normative angle has to do with the Court's contribution to interpreting and developing international human rights law rules and principles and to laying down standards of conduct for States, international organisations and their organs, other legal entities and even individuals. The Court has dealt not only with the right to self-determination within the decolonisation context and the scope of human rights protection under the Genocide Convention, the CAT and the CERD, but also with the territorial scope of human rights treaties' obligations, aspects of attribution of State responsibility and issues concerning reparations for internationally wrongful acts. From an institutional angle, it is important to place the contribution of the ICJ within the context of supporting the achievement of the main purposes of the UN. Notably, this includes ensuring the independence and inviolability of UN human rights rapporteurs (experts on mission), the constructive interpretation of the functions of the General Assembly and the Security Council in matters of international peace and security and their monitoring of compliance with international human rights obligations. These important aspects of the work of the Court are analysed in more detail in the subsections below.

\subsection{Procedural Aspects of the Court's Activity}

\footnotetext{
${ }^{52}$ CRPD, New York, 13 December 2006, in force 3 May 2008, 2515 UNTS 3.

${ }^{53}$ The only two new developments have been the adoption of the Optional Protocol to the Covenant on Economic, Social and Cultural Rights, New York, 10 December 2008, in force 5 May 2013, UN Doc. A/63/435 (2008); C.N.869.2009, and the Optional Protocol to the Convention on the Rights of the Child on a Communications Procedure, New York, 19 December 2011, in force 14 April 2014, GA Res. 66/138 (2011).

${ }^{54}$ Simma, 'Community Interest Coming to Life', pp. 301-25, especially 303-17.
} 
The Rules of Court and the Practice Directions adopted by the ICJ aim at ensuring the good administration of international justice. The procedural rules at the ICJ facilitate the legal process and allow the parties appearing before the Court the same possibility to put forward their case. This does not change the fact that individuals do not have direct access to the Court, ${ }^{55}$ nor that the Court's contentious jurisdiction is based on State consent. The next three subsections will analyse more closely the issue of access to international justice, diplomatic protection and the nationality link, and the category of cases involving matters of general concern to the international community.

\subsubsection{Access to International Justice through the ICJ}

Direct or indirect access to international justice is crucial for individuals to claim and vindicate their human rights. In this regard, the ICJ faces a number of limitations. First, the ICJ is not open to individuals, nor is it going to be any time soon. While States and the main organs of the UN have brought several cases concerning human rights before the Court, there is no formal obligation for them do so as a matter of diplomatic protection or otherwise, even in case of violations of jus cogens norms. Second, the number of States that have accepted the Court's jurisdiction under Article 36(2) of its Statute remains limited. ${ }^{56}$ The unwillingness of States to accept the Court's compulsory jurisdiction together with the paucity of compromissory clauses in international human rights and humanitarian law treaties significantly limit the ICJ's possibility to adjudicate serious human rights violations. Moreover, States can avoid the jurisdiction of the Court by entering reservations to the compromissory clauses of the human rights treaties. Finally, the jurisdiction of the Court is based on State consent and the Court has respected this important requirement even when it has meant that claims of violations of jus cogens norms, such as the prohibition of genocide, cannot be adjudicated on the merits.

\subsubsection{Diplomatic Protection and the Nationality Link}

Diplomatic protection is the oldest tool available to States to protect their nationals against human rights violations when abroad. While a person can expect its State of nationality to protect them, especially in cases of serious violations of human rights, bringing a case before the ICJ remains at the discretion of the State concerned. That notwithstanding, the ICJ's case law demonstrates that States have had recourse to diplomatic protection on many occasions, although the solution in many of these cases was reached out of court. ${ }^{57}$ Some of the main cases brought by way of diplomatic protection include Nottebohm, ${ }^{58}$ Interhandel, ${ }^{59}$ Barcelona

\footnotetext{
${ }^{55}$ For a detailed discussion see inter alia Martin Scheinin, 'The ICJ and the Individual', International Community Law Review 9 (2007), 123-137.

${ }^{56}$ As of 1 January 2018, 73 out of the 193 UN member States have accepted the Court's jurisdiction under this provision.

${ }^{57}$ Most of the cases brought before the ICJ are based on diplomatic protection. Between 1949, with the Case Concerning the Protection of French Nationals and Protected Persons in Egypt (France v. Egypt), ICJ Reports (1950) 59, to 2017 with the Jadhav Case (India v. Pakistan), ICJ Reports (2017) 231, there have been 42 cases submitted before the Court. Many of these cases were subsequently withdrawn. $C f$. K. Parlett, 'Diplomatic Protection and the International Court of Justice', in Tams and Sloan, 'Development of International Law', p. 105 (referring to 11 cases).

${ }^{58}$ Nottebohm Case (Liechtenstein v. Guatemala), ICJ Reports (1955) 4.

${ }^{59}$ Interhandel Case (Switzerland v. United States of America), ICJ Reports (1959) 6.
} 
Traction, ${ }^{60}$ Tehran Hostages, ${ }^{61}$ ELSI, ${ }^{62}$ Oil Platforms, ${ }^{63}$ Arrest Warrant ${ }^{64}$ and Diallo ${ }^{65}$ There are also four cases concerning the application of the Vienna Convention on Consular Relations, namely Breard, LaGrand, Avena and the recent Jadhav case.

While at their core these cases concern the protection of individuals or the interests of shareholders and corporations, the ICJ has noted that 'Diplomatic protection and protection by means of international judicial proceedings constitute measures for the defence of the rights of the State. ${ }^{, 66}$ The rights subject to dispute include the right to property, the right to security and freedom from arbitrary arrest and detention, the right to a fair trial, the right not to be subjected to torture or inhuman and degrading treatment, the right to just compensation for expropriated assets, and equal treatment before the courts. Most of these rights can be seen as basic rights of aliens under international law. ${ }^{67}$ The rights invoked include not only civil and political rights, but also economic, social and cultural rights.

An important aspect of the exercise of diplomatic protection is the nationality link. In the Nottebohm case, the Court gave a definition of nationality, namely: '[N]ationality is a legal bond having as its basis a social fact of attachment, a genuine connection of existence, interests and sentiments, together with the existence of reciprocal rights and duties. ${ }^{68}$ The Court also found that 'a State cannot claim that the rules it has thus laid down are entitled to recognition by another State unless it has acted in conformity with this general aim of making the legal bond of nationality accord with the individual's genuine connection with the State which assumes the defence of its citizens by means of protection as against other States' ${ }^{69}$ The Court has emphasised the need for a genuine link between a naturalised person and his/her State of nationality, which needs to be expressed in that person 'becoming wedded to [that State's] traditions, its interests, its way of life or of assuming the obligations - other than fiscal obligations - and exercising the rights pertaining to the status thus acquired' ${ }^{70}$ In terms of protection for corporations and shareholders, the Court has taken the view that the only country that can vindicate the rights of these corporations is the country where the corporation is registered. This position has created certain problems concerning the protection of property rights, which have been addressed mainly through the establishment of bilateral investment treaties (BITs) and investor-State dispute settlement mechanisms.

\subsubsection{Cases Involving Matters of General Concern to the International Community}

Although a somewhat rare occurrence in the activity of the Court over the last 70 years, an important category of human rights cases brought before the ICJ through its contentious or

\footnotetext{
${ }^{60}$ Case Concerning the Barcelona Traction, Light and Power Company, Limited (New Application: 1962) (Belgium v. Spain), ICJ Reports (1970) 3.

${ }^{61}$ Case Concerning United States Diplomatic and Consular Staff in Tehran (United States of America v. Iran), ICJ Reports (1980) 3.

${ }^{62}$ Case Concerning Elettronica Sicula S.p.A. (ELSI) (United States of America v. Italy), ICJ Reports (1989) 15.

${ }^{63}$ Case Concerning Oil Platforms (Islamic Republic of Iran v. United States of America), ICJ Reports (2003) 161.

${ }^{64}$ Case Concerning the Arrest Warrant of 11 April 2000 (Democratic Republic of the Congo v. Belgium), ICJ Reports (2002) 3.

${ }^{65}$ See inter alia Parlett, 'Diplomatic Protection', pp. 87-106, especially pp. 93-103.

${ }^{66}$ Nottebohm, 24.

${ }^{67}$ See among others R. B. Lillich, The Human Rights of Aliens in Contemporary International Law (Manchester: Manchester University Press, 1984); S. M. Schwebel, 'The Treatment of Human Rights and of Aliens in the International Court of Justice', in V. Lowe and M. Fitzmaurice (eds.), Fifty Years of the International Court of Justice: Essays in Honour of Sir Robert Jennings (CUP 1996), pp. 327-50.

${ }^{68}$ Nottebohm Case, 23.

${ }^{69}$ Ibid.

${ }^{70}$ Ibid., 26.
} 
advisory jurisdiction concern matters of general concern to the international community. ${ }^{71}$ Most of these cases involve General Assembly requests for advisory opinions. Only six cases involve inter-State complaints about disputes concerning human rights issues broadly construed, brought before the ICJ by a third party. ${ }^{72}$ Simma has referred to such cases as "community interest coming to life'. ${ }^{73}$ Community interests have been described 'as a consensus according to which respect for certain fundamental values is not to be left to the free disposition of States individually or inter se but is recognized and sanctioned by international law as a matter of concern to all States'. ${ }^{74}$ While the articulation and protection of community interests has a permanent place on the agenda of the UN and other international and regional bodies, not many such issues have made it to the docket of the ICJ.

Categorising these cases based on the specific issues concerned, we can distinguish the following general topics:

1) The scope of reservations to human rights treaties;

2) The right of peoples to self-determination in the context of the process of decolonisation;

3) The ban on nuclear weapons and the process of nuclear disarmament; and

4) The obligation to prosecute or extradite persons alleged to have committed serious human rights and humanitarian law violations (torture).

The General Assembly has requested an advisory opinion from the ICJ concerning reservations to the Genocide Convention; ${ }^{75}$ concerning the threat or use of nuclear weapons $;{ }^{76}$ and on a number of (technical) issues relating to the right of peoples to self-determination in South West Africa, ${ }^{77}$ on Western Sahara ${ }^{78}$ and on Palestine ${ }^{79}$. So far, the ICJ has never declined to answer a request for an advisory opinion brought by the main UN organs, namely the General Assembly and the Security Council. When it comes to the six contentious cases, two concerned South West Africa; one concerned the obligation to prosecute or extradite persons alleged to have committed acts of torture under the CAT; and three concerned nuclear disarmament. Only one of these cases was decided by the Court on the merits, whereas the others did not pass the preliminary objections stage. From this perspective, advisory opinions seem to provide a better

\footnotetext{
${ }^{71}$ See inter alia G. I. Hernández, 'A Reluctant Guardian: The International Court of Justice and the Concept of "International Community”, British Yearbook of International Law, 83 (2013), 13-60.

${ }^{72}$ South West Africa Cases (Ethiopia v. South Africa; Liberia v. South Africa), ICJ Reports (1966) 6; Obligation to Prosecute or Extradite; Obligations concerning Negotiations relating to Cessation of the Nuclear Arms Race and to Nuclear Disarmament (Marshall Islands v. United Kingdom), ICJ Reports (2016) 833; Obligations concerning Negotiations relating to Cessation of the Nuclear Arms Race and to Nuclear Disarmament (Marshall Islands v. Pakistan), ICJ Reports (2016) 552; Obligations concerning Negotiations relating to Cessation of the Nuclear Arms Race and to Nuclear Disarmament (Marshall Islands v. India), ICJ Reports (2016) 255.

${ }^{73}$ Simma, 'Community Interest Coming to Life'.

${ }^{74}$ B. Simma, 'From Bilateralism to Community Interest in International Law', in Recueil des Cours (Collected Courses of the Hague Academy of International Law), vol. 250 (1994), (Leiden: Martinus Nijhoff Publishers, 1997), p. 233.

${ }^{75}$ Reservations to the Convention on the Prevention and Punishment of the Crime of Genocide, ICJ Reports (1951) 15.

${ }^{76}$ Legality of the Threat or Use of Nuclear Weapons, ICJ Reports (1996) 226.

${ }^{77}$ International Status of South-West Africa, ICJ Reports (1950) 128; Voting Procedure on Questions relating to Reports and Petitions concerning the Territory of South-West Africa, ICJ Reports (1955) 67; Admissibility of Hearings of Petitioners by the Committee on South West Africa, ICJ Reports (1956) 23. The last advisory opinion on South West Africa was requested by the Security Council, Legal Consequences for States of the Continued Presence of South Africa in Namibia (South West Africa) notwithstanding Security Council Resolution 276 (1970), ICJ Reports (1971) 16.

${ }^{78}$ Western Sahara, ICJ Reports (1975) 12.

${ }^{79}$ Wall.
} 
vehicle to get legal advice from the ICJ on issues of general concern to the international community.

Several potential cases which concern contemporary matters of general concern to the international community could be brought before the Court by the General Assembly or individual States on the basis of inter-State complaints option included in some of the human rights treaties. A non-exhaustive list would include issues concerning forced labour or child labour; clarifying the legal obligations of States parties to the 2015 Paris Accords concerning countering climate change $;^{80}$ obligations of States and the UN to bring about a durable and just solution to the Palestinian-Israeli conflict; the obligations of States and international and regional organisations to restore peace in Syria; and so on.

\subsection{Normative Aspects of the Court's Activity}

From a normative perspective, the ICJ has interpreted and developed several basic human rights. Thus, the Court has addressed important collective human rights, such as the right to self-determination in the context of the process of decolonisation, or individual human rights, such as the right to life, the prohibition of genocide, the prohibition of torture and so on. The Court's position has been cautious, even when positively inclined towards human rights. ${ }^{81}$ Hernández has pointed out that the ICJ is ambivalent in respect of jus cogens norms and obligations erga omnes, invoking 'these concepts in a legally inconsequential manner, an "empty box" of sorts". ${ }^{82}$ The three issues selected for a more detailed analysis are the right of peoples to self-determination, the prohibition of genocide and the prohibition of torture. These issues are important to human rights enjoyment and protection and the Court has addressed them in some detail in its case law.

\subsubsection{Decolonisation and Self-Determination of Peoples}

Several cases relate to the self-determination of peoples in the context of decolonisation. ${ }^{83}$ Most of them concern the protracted process of decolonisation of South West Africa, now Namibia, including two joined contentious cases resulting in an infamous judgment in 1966 and four advisory opinions, three requested by the General Assembly and the last one requested by the Security Council. One advisory opinion concerns Western Sahara. A more recent advisory opinion, rendered in July 2004, concerns the Occupied Palestinian Territory. The last advisory opinion, rendered in July 2010, concerns the declaration of independence of Kosovo, but the Court did not address the right to self-determination. A pending advisory opinion concerns the Chagos Archipelago and the process of decolonisation with regard to Mauritius.

Higgins has aptly observed that Court was the forerunner in recognising self-determination as a legal right, given that at that time 'there were still many within the UN who insisted that self-determination was nothing more than a political aspiration'. ${ }^{84}$ Based on an analysis of the internal dynamics within the Court, Kattan has concluded that the Namibia decision 'marked the moment [when] the ICJ [itself] went through decolonization' ${ }^{85}$ Importantly, the Court has found that 'the right of peoples to self-determination, as it evolved from the Charter and from

\footnotetext{
${ }^{80}$ Paris Agreement, Paris, 12 December 2015, in force 4 November 2016, Secretariat of the UN, Registration No. 54113.

${ }^{81}$ See inter alia Hernández, 'Reluctant Guardian', 13-60.

${ }^{82}$ Hernández, 'Reluctant Guardian', 58.

${ }^{83}$ For a detailed discussion of this issue see inter alia G. Zyberi, 'Self-Determination through the Lens of the International Court of Justice', Netherlands International Law Review, 56 (2009), 429-53.

${ }^{84}$ Higgins, 'Human Rights', 747.

${ }^{85}$ V. Kattan, 'Decolonizing the International Court of Justice: The Experience of Judge Sir Muhammad Zafrulla Khan in the South West Africa Cases', Asian Journal of International Law, 5 (2015), 353.
} 
United Nations practice, has an erga omnes character' ${ }^{86}$ In its 1971 advisory opinion, the Court specifically noted that 'the ultimate objective of the sacred trust [referred to in Article 22(1) of the Covenant of the League of Nations] was the self-determination and independence of the peoples concerned' ${ }^{87}$ This finding clarified the generally expected result of the process of decolonisation for non-self-governing territories.

With regard to the situation of Western Sahara, after noting that 'its answer is requested in order to assist the General Assembly to determine its future decolonization policy and in particular to pronounce on the claims of Morocco and Mauritania to have had legal ties with Western Sahara involving the territorial integrity of their respective countries', ${ }^{88}$ the ICJ observed that it had not found legal ties (with Morocco or Mauritania) 'of such a nature as might affect the application of resolution 1514(XV) in the decolonization of Western Sahara and, in particular, of the principle of self-determination through the free and genuine expression of the will of the peoples of the Territory'. ${ }^{89}$ The situation of Western Sahara remains unresolved, despite continued efforts on the part of the UN to negotiate a just, lasting, and mutually acceptable political solution, which will provide for the self-determination of the people of Western Sahara. ${ }^{90}$ Interestingly, the December 2016 General Assembly resolution on Western Sahara makes no mention of the ICJ advisory opinion of 1975.

With regard to the right to self-determination of the Palestinian people, the ICJ has found a number of obligations incumbent upon Israel, all (UN member) States, as well as on the UN General Assembly. The Court has noted that Israel has 'to comply with its obligation to respect the right of the Palestinian people to self-determination'. ${ }^{91}$ Moreover, the Court has also concluded 'that the Israeli settlements in the Occupied Palestinian Territory (including East Jerusalem) have been established in breach of international law' ${ }^{92}$ The Court has clarified that all States are under a threefold obligation, namely

a) 'an obligation not to recognize the illegal situation resulting from the construction of the wall in the Occupied Palestinian Territory, including in and around East Jerusalem';

b) 'an obligation not to render aid or assistance in maintaining the situation created by such construction'; and

c) 'while respecting the United Nations Charter and international law, to see to it that any impediment, resulting from the construction of the wall, to the exercise by the Palestinian people of its right to self-determination is brought to an end' ${ }^{93}$

Finally, the Court has drawn the attention of the General Assembly 'to the need for [...] efforts to be encouraged with a view to achieving as soon as possible, on the basis of international law, a negotiated solution to the outstanding problems and the establishment of a Palestinian State, existing side by side with Israel and its other neighbours, with peace and security for all in the region'. ${ }^{94}$ More recently, France has launched an international peace initiative through meetings

\footnotetext{
${ }^{86}$ Wall, para. 156.

${ }^{87}$ South Africa in Namibia, para. 53.

${ }^{88}$ Western Sahara, para. 161.

${ }^{89}$ Ibid., para. 162.

${ }^{90}$ See Question of Western Sahara, UNGA Res. A/RES/71/106, 6 December 2016. See also Special Committee on the Situation with regard to the Implementation of the Declaration on the Granting of Independence to Colonial Countries and Peoples, Question of Western Sahara (continued) (Hearing of Representatives of the Non-SelfGoverning Territory), Summary of Meeting, UN Doc. A/AC.109/2016/SR.5, 17 June 2016.

${ }^{91}$ Wall, para. 149.

${ }^{92}$ Ibid., para. 120. See also more generally T. Meron, 'The West Bank and International Humanitarian Law on the Eve of the Fiftieth Anniversary of the Six-Day War', American Journal of International Law, 111 (2017), 357-75.

${ }^{93}$ Wall, para. 159.

${ }^{94}$ Ibid., para. 162.
} 
organised in June 2016 and January $2017 .{ }^{95}$ In its November 2016 resolution on Palestine, the General Assembly has called for "[t]he withdrawal of Israel from the Palestinian territory occupied since 1967, including East Jerusalem', ${ }^{96}$ as well as 'the realization of the inalienable rights of the Palestinian people, primarily the right to self-determination and the right to their independent State' ${ }^{97}$ A durable and just solution to this long-standing conflict remains elusive and the peace process has stalled in the last decades.

\subsubsection{Human Rights Protection under the Genocide Convention}

The Court has addressed several aspects of the prohibition of genocide under international law. First, in an advisory opinion rendered in 1951 it addressed the issue of State reservations to the Genocide Convention. More recently, the Court has addressed the issue of the definition of the protected groups and the special intent required for the crime of genocide, as well as relevant State obligations, including the duty to punish, the duty to prevent and the duty to cooperate with international criminal courts prosecuting individuals for the crime of genocide.

\subsubsection{Reservations to the Genocide Convention}

The Court has emphasised the 'purely humanitarian and civilizing purpose' of this convention. ${ }^{98}$ Moreover, the Court has highlighted two consequences arising from the nature of the convention: 'The first consequence [...] is that the principles underlying the Convention are principles which are recognized by civilized nations as binding on States, even without any conventional obligation. A second consequence is the universal character both of the condemnation of genocide and of the co-operation required "in order to liberate mankind from such an odious scourge" (Preamble to the Convention). ${ }^{99}$ These legal findings emphasise the customary international law, as well as the erga omnes nature of State obligations concerning the prohibition of genocide. However, the Court's position concerning reservations to the Genocide Convention remains ambivalent. On the one hand, the Court has restricted the ability of States to enter broad reservations that go against the object and purpose of this convention; on the other hand, it has allowed them to exclude the Court's jurisdiction to adjudicate on potential violations, even when this is the only possible venue for the adjudication of such disputes.

Thus, with regard to State reservations to the Genocide Convention, the Court has found that " $\mathrm{t}] \mathrm{he}$ object and purpose of the Convention [...] limit both the freedom of making reservations and that of objecting to them'. ${ }^{100}$ At the same time, the Court has found 'that the mere fact that rights and obligations erga omnes or peremptory norms of general international law (jus cogens) are at issue in a dispute cannot in itself constitute an exception to the principle that its jurisdiction always depends on the consent of the parties'. ${ }^{101}$ According to the Court, 'no such norm [...] exists requiring a State to consent to the jurisdiction of the Court in order to settle a dispute relating to the Genocide Convention'. ${ }^{102}$ In a separate opinion, five ICJ judges

\footnotetext{
${ }^{95}$ For more information on the French initiative see 'Initiative for the Middle East Peace Process', Ministry for Europe and Foreign Affairs of France, available at: www.diplomatie.gouv.fr/en/country-files/israel-palestinianterritories/peace-process/initiative-for-the-middle-east-peace-process.

${ }^{96}$ Peaceful Settlement of the Question of Palestine, UNGA Res. A/RES/71/23, 30 November 2016, para. 22(a).

${ }^{97}$ Ibid., para. 22(b).

${ }^{98}$ Reservations to the Genocide Convention, 23.

${ }^{99}$ Ibid.

100 Ibid., 24.

101 Case Concerning Armed Activities on the Territory of the Congo (New Application: 2002) (Democratic Republic of the Congo v. Rwanda), ICJ Reports (2006) 6, para. 125.

${ }^{102}$ Armed Activities (New Application), para. 69.
} 
noted that "[i]t is a matter for serious concern that at the beginning of the twenty-first century it is still for States to choose whether they consent to the Court adjudicating claims that they have committed genocide'. ${ }^{103}$ This author wholeheartedly agrees with these judges' assertion that '[i]t is [...] not self-evident that a reservation to Article IX could not be regarded as incompatible with the object and purpose of the Convention and [...] that this is a matter that the Court should revisit for further consideration'. ${ }^{104}$ An intermediate solution could be to set aside a State reservation to Article IX of the Genocide Convention only in cases where there is no other available remedy for a State to adjudicate a dispute concerning the fulfilment of this convention.

\subsubsection{Definition of the Protected Group and Special Intent}

The Court has noted: "[T]he "intent to destroy, in whole or in part, a national, ethnical, racial or religious group as such" is the essential characteristic of genocide, which distinguishes it from other serious crimes'. ${ }^{105}$ With regard to the definition of the protected group under the Genocide Convention, the Court has stated that '[i]t is a group which must have particular positive characteristics - national, ethnical, racial or religious — and not the lack of them'. ${ }^{106}$ The Court has cited Lemkin's work, the Nuremberg indictment, the drafting history of the Genocide Convention, General Assembly Resolution 96(I) (1946), its own 1951 advisory opinion, and the ICTY Appeals Chamber judgment in the Stakic case, to support such an understanding of the protected group. ${ }^{107}$ Moreover, the Court has found that 'The rejection of proposals to include within the Convention political groups and cultural genocide demonstrates that the drafters were giving close attention to the positive identification of groups with specific distinguishing, well-established, some said immutable, characteristics. ${ }^{108}$ The Court has put to rest claims of cultural genocide, holding that the protection of the Genocide Convention is aimed at the physical protection of the group. ${ }^{109}$

In terms of determining a 'part' of the group under Article II of the Genocide Convention, the Court has pointed out three necessary elements, namely substantiality, opportunity and quality. On the basis of the first criterion, 'the intent must be to destroy at least a substantial part of the particular group' $;{ }^{110}$ under the second criterion, 'genocide may be found to have been committed where the intent is to destroy the group within a geographically limited area', ${ }^{111}$ and under the third criterion, '[i]f a specific part of the group is emblematic of the overall group, or is essential to its survival, that may support a finding that the part qualifies as substantial'. ${ }^{112}$ The Court has held that in evaluating whether the allegedly targeted part of a protected group is substantial in relation to the overall group, it will take into account the quantitative element as well as evidence regarding the geographic location and prominence of the allegedly targeted part of the group. ${ }^{113}$ Importantly, these findings of the Court concerning the jus cogens status of the prohibition of genocide and certain constituent elements of the crime

\footnotetext{
${ }^{103}$ Ibid., Joint Separate Opinion by Judges Higgins, Kooijmans, Elaraby, Owada and Simma, para. 25.

${ }^{104}$ Ibid., para. 29.

105 The Genocide case II, para. 132.

106 The Genocide case I, para. 193.

${ }^{107}$ Ibid., paras. 193-5. Prosecutor v. Stakić, ICTY Case No. IT-97-24-A, Judgment, 22 March 2006.

108 Ibid., para. 194.

109 Ibid., para. 344, concluding that 'the destruction of historical, religious and cultural heritage cannot be considered to be a genocidal act within the meaning of Article II of the Genocide Convention'. See also the Genocide case II, para. 136.

110 The Genocide case I, para. 198.

${ }^{111}$ Ibid., para. 199.

${ }^{112}$ Ibid., para. 200, citing the Krstić Appeals Chamber judgment. Prosecutor v. Krstić, ICTY Case No. IT-98-33A, Judgment, 19 April 2004.

113 The Genocide case II, para. 142.
} 
of genocide, such as special intent and the definition of the group, have proven relevant for criminal legal proceedings before the ad hoc UN tribunals for the former Yugoslavia and for Rwanda. There has been cross-referencing to the case law of each other; by the ICJ to ICTY case law in the two inter-State cases concerning genocide, and by the ad hoc tribunals, which have cited with approval some of the ICJ's findings concerning the crime of genocide. ${ }^{114}$ These findings by the ICJ have proven important for the application of the Genocide Convention by other international courts.

\subsubsection{State Obligations Concerning the Crime of Genocide}

Concerning the duty to prevent, the Court has held that ' $[\mathrm{t}]$ he obligation on each contracting State to prevent genocide is both normative and compelling [...] [and this duty] has its own scope, which extends beyond the particular case envisaged in Article VIII, namely reference to the competent organs of the United Nations, [in order] for them to take such action as they deem appropriate'. ${ }^{115}$ As the Court has noted, '[e]ven if and when these organs have been called upon, this does not mean that the States parties to the Convention are relieved of the obligation to take such action as they can to prevent genocide from occurring, while respecting the United Nations Charter and any decisions that may have been taken by its competent organs'. ${ }^{116}$ Probably the most important clarification in terms of the law on international responsibility is the finding that the obligation under the duty to prevent 'is one of conduct and not one of result, in the sense that a State cannot be under an obligation to succeed, whatever the circumstances, in preventing the commission of genocide: the obligation of States parties is rather to employ all means reasonably available to them, so as to prevent genocide so far as possible'. ${ }^{117}$ This finding endorses the concept of shared responsibility among States, individually, jointly and in the context of international organisations. ${ }^{118}$

Alongside the concept of shared responsibility, the ICJ has introduced the concept of 'due diligence' and a number of criteria for assessing State conduct in preventing genocide. The first criterion, 'which varies greatly from one State to another, is clearly the capacity to influence effectively the action of persons likely to commit, or already committing, genocide' ${ }^{119}$ This capacity depends on objective criteria, such as 'the geographical distance of the State concerned from the scene of the events, and [...] the strength of the political links, as well as links of all other kinds, between the authorities of that State and the main actors in the events'. ${ }^{20}$ The legal criteria for assessing this capacity include the limits imposed by international law, given that 'a State's capacity to influence may vary depending on its particular legal position vis-à-vis the situations and persons facing the danger, or the reality, of genocide'. ${ }^{121}$ Taken together, these criteria seem to require a more active role especially on the

\footnotetext{
${ }^{114}$ See inter alia Prosecutor v. Tolimir, ICTY Case No. IT-05-88/2-A, Judgment, 8 April 2015, paras. 226-231; Prosecutor v. Blagojević and Jokić, ICTY Case No. IT-02-60-T, Judgment, 17 January 2005, para. 639; Prosecutor v. Galić, ICTY Case No. IT-98-29-T, Judgment and Opinion, 5 December 2003, para. 45; Prosecutor v. Kupreškić et al, ICTY Case No. IT-95-16-T, Judgment, 14 January 2000, para. 519; Prosecutor v. Jelisić, ICTY Case No. IT-95-10-T, Judgment, 14 December 1999, para. 60; Prosecutor v. Akayesu, ICTR-96-4-T, Judgment, 2 September 1998, para. 495.

115 The Genocide case I, para. 427.

116 Ibid.

${ }^{117}$ Ibid., para. 430.

118 See inter alia A. Nollkaemper and I. Plakokefalos (eds.), Principles of Shared Responsibility in International Law: An Appraisal of the State of the Art (New York: Cambridge University Press, 2014); A. Nollkaemper and I. Plakokefalos (eds.), The Practice of Shared Responsibility in International Law (Cambridge: Cambridge University Press, 2017).

119 The Genocide case I, para. 430.

${ }^{120}$ Ibid.

121 Ibid.
} 
part of neighbouring States, regional organisations and the permanent members of the UN Security Council.

The Court has drawn a clear distinction between the duty to prevent genocide and complicity in committing genocide by noting that 'complicity always requires some positive action [...] taken to furnish aid or assistance to the perpetrators of the genocide, while a violation of the obligation to prevent results from mere failure to adopt and implement suitable measures to prevent genocide from being committed'. ${ }^{122}$ Another distinction was drawn concerning the element of knowledge, where the Court clarified that 'an accomplice must have given support in perpetrating the genocide with full knowledge of the facts', whereas concerning the duty to prevent it is enough that 'the State was aware, or should normally have been aware, of the serious danger that acts of genocide would be committed'. ${ }^{123}$ These findings ensure more clarity in the context of the law of international responsibility and provide States with some general guidance concerning steps their international legal obligations concerning genocide prevention.

The Court has also clarified the scope of State obligations concerning the duty to punish individual perpetrators of genocide. With regard to the reach of investigations and prosecutions at the domestic level, the Court has clarified that Article VI of the Genocide Convention 'only obliges the Contracting Parties to institute and exercise territorial criminal jurisdiction'. ${ }^{124}$ As the Court has found, while Article VI 'certainly does not prohibit States [...] from conferring jurisdiction on their criminal courts based on criteria other than where the crime was committed which are compatible with international law, in particular the nationality of the accused, it does not oblige them to do so'. ${ }^{125}$ With this finding, the Court has emphasised territorial jurisdiction and has left extending jurisdiction extraterritorially at the discretion of the States parties to the Genocide Convention.

With regard to a State's obligation to cooperate with international criminal courts with jurisdiction over the crime of genocide, the ICJ has clarified that Article VI of the Genocide Convention 'obliges the Contracting Parties "which shall have accepted its jurisdiction" to cooperate with' such courts. ${ }^{126}$ This 'implies that they will arrest persons accused of genocide who are in their territory - even if the crime of which they are accused was committed outside it - and, failing prosecution of them in the parties' own courts, that they will hand them over for trial by the competent international tribunal'. ${ }^{127}$ The Court has construed broadly ' $[\mathrm{t}] \mathrm{he}$ notion of an "international penal tribunal" within the meaning of Article VI', ${ }^{128}$ stating that it 'must at least cover all international criminal courts created after the adoption of the Convention [...] of potentially universal scope, and competent to try the perpetrators of genocide or any of the other acts enumerated in Article III' ${ }^{129}$ As the Court has emphasised, '[ $t$ ]he nature of the legal instrument by which such a court is established is without importance in this respect'. ${ }^{130}$ Considering that the prevention and the punishment of the crime of genocide are of paramount importance for the international community and that the prohibition of genocide is a jus cogens norm, arguably States parties to the Genocide Convention would have a prima facie obligation to cooperate with the International Criminal Court (ICC) concerning the investigation and prosecution of the crime of genocide, even if they are not parties to the ICC Statute.

\footnotetext{
${ }^{122}$ Ibid., para. 432.

123 Ibid.

${ }^{124}$ Ibid., para. 442.

125 Ibid.

${ }^{126}$ Ibid., para. 443.

${ }^{127}$ Ibid.

${ }^{128}$ Ibid., para. 445.

${ }^{129}$ Ibid.

${ }^{130}$ Ibid.
} 


\subsubsection{The Prohibition of Torture and Other Cruel, Inhuman or Degrading Treatment or Punishment}

The prohibition of torture and other cruel, inhuman or degrading treatment or punishment is another key human right that has been elaborated by the Court. Two cases are primarily relevant for this discussion, namely Obligation to Prosecute or Extradite brought by Belgium under Article 30(1) of the CAT and Diallo brought by Guinea. Through these cases the Court has established the nature of the prohibition of torture and other cruel, inhuman or degrading treatment or punishment and the obligations incumbent upon a State under Article 7(1) of the CAT, namely the obligation to prosecute or extradite.

With regard to the issue of legal standing, the Court has found: 'The common interest in compliance with the relevant obligations under the Convention against Torture implies the entitlement of each State party to the Convention to make a claim concerning the cessation of an alleged breach by another State party. ${ }^{131}$ This finding allows a State party to the CAT to bring an inter-State complaint against another State before the ICJ. Applied by analogy to other human rights treaties that contain a compromissory clause, this would enable third States to bring complaints about egregious violations of human rights before the ICJ.

The Court has acknowledged that 'the prohibition of torture is part of customary international law and it has become a peremptory norm (jus cogens)' ${ }^{132}$ Furthermore, the Court has also found that 'the prohibition of inhuman and degrading treatment is among the rules of general international law which are binding on States in all circumstances, even apart from any treaty commitments'. ${ }^{133}$ In terms of State obligations under Article 7(1) of the CAT, the Court has noted that this provision 'requires the State concerned to submit the case to its competent authorities for the purpose of prosecution, irrespective of the existence of a prior request for the extradition of the suspect'. ${ }^{134}$ In interpreting the relationship between prosecution and extradition under the CAT, the Court has held that '[e]xtradition is an option offered to the State by the Convention, whereas prosecution is an international obligation under the Convention, the violation of which is a wrongful act engaging the responsibility of the State'. ${ }^{135}$ The Court has noted that on the basis of Article 27 of the Vienna Convention on the Law of Treaties, ${ }^{136}$ a State cannot justify breaches of Article 7(1) of the CAT 'by invoking provisions of its internal law [...] or the fact that it did not adopt the necessary legislation pursuant to [Article 5(2) of the CAT]'. ${ }^{137}$ The Court has further emphasised that obligations under Article 7(1) of the CAT 'must be implemented within a reasonable time, in a manner compatible with the object and purpose of the Convention'. ${ }^{138}$ Ultimately, '[t]he purpose of these treaty provisions is to prevent alleged perpetrators of acts of torture from going unpunished, by ensuring that they cannot find refuge in any State party'. ${ }^{139}$ These findings of the ICJ have clarified the nature of the prohibition of torture, as well as several aspects of State obligations under the CAT, including the obligation to prosecute or extradite.

\subsection{Institutional Aspects of the Court's Activity}

\footnotetext{
131 Obligation to Prosecute or Extradite, para. 69.

132 Ibid., para. 99.

${ }^{133}$ Diallo (2010), para. 87.

${ }^{134}$ Obligation to Prosecute or Extradite, para. 94.

135 Ibid., para. 95.

136 Vienna Convention on the Law of Treaties, Vienna, 23 May 1969, in force 27 January 1980, UN Doc. A/Conf.39/27; 1155 UNTS 331, Article 27.

${ }^{137}$ Obligation to Prosecute or Extradite, para. 113.

${ }^{138}$ Ibid., para. 114

${ }^{139}$ Ibid., para. 120.
} 
From the very beginning of its activity, the Court has emphasised that a request for an advisory opinion 'represents its participation in the activities of the Organization, and, in principle, should not be refused'. ${ }^{140}$ Hence, the ICJ's contribution should be placed in its proper institutional context, its function and engagement with human rights having evolved as part of the activity of the UN, where human rights protection figures prominently. ${ }^{141}$ First, the Court has assisted the main UN organs by providing them with legal advice on different human rights issues. That said, the main UN organs have not made extensive use of the ICJ's advisory function, preferring to act in ways they have deemed adequate. Second, the Court has anchored State obligations concerning human rights on relevant provisions of the UN Charter and the International Bill of Rights. Third, the Court's own institutional composition has served as a model for establishing other international judicial mechanisms. In the next subsections, we will address the contribution of the Court to the UN's work on ensuring international peace and security and the prohibition on the use of force, ${ }^{142}$ and the legal protection for UN special human rights rapporteurs under the Convention on the Privileges and Immunities of the United Nations.

\subsubsection{International Peace and Security and the Prohibition on the Use of Force}

The Court's findings concerning the general prohibition on the use of force and the relationship between the main UN organs concerning the maintenance of international peace and security are discussed together in this subsection. The first concerns the general prohibition of the unilateral use of force, as codified in the UN Charter and also as part of customary international law. The second issue concerns the Court's purposive interpretation of Article 17 of the UN Charter, enabling the General Assembly to finance peacekeeping operations under the UN budget, and the working relationship between the General Assembly and the Security Council in matters of international peace and security. Both issues are very important for ensuring international peace and security, which is central to the UN mandate.

The option of using force as a means to enforce human rights in another country was argued in the Nicaragua case. The Court found that 'while the United States might form its own appraisal of the situation as to respect for human rights in Nicaragua, the use of force could not be the appropriate method to monitor or ensure such respect'. ${ }^{143}$ In emphasising the principle of peaceful settlement of disputes, the Court drew the parties attention to 'the need to co-operate with the Contadora efforts in seeking a definitive and lasting peace in Central America, in accordance with the principle of customary international law that prescribes the peaceful settlement of international disputes'. ${ }^{144}$ In more recent years there has been a rise in the unilateral use of force in violation of the UN Charter, including in Iraq and Syria. Such military interventions can further exacerbate human rights violations in these countries.

The Court has addressed the powers of the General Assembly and the Security Council concerning peacekeeping. In the Certain Expenses advisory opinion, which concerned UN peace operations for Congo and the Middle East, the Court interpreted the powers of the General Assembly under Article 17 of the UN Charter, so as to allocate the budget in a manner so as to

\footnotetext{
${ }^{140}$ Interpretation of Peace Treaties with Bulgaria, Hungary and Romania, ICJ Reports (1950) 65, 71; Difference Relating to Immunity from Legal Process of a Special Rapporteur of the Commission on Human Rights, ICJ Reports (1999) 62, para. 29 (Cumaraswamy); Wall, para. 44.

${ }^{141}$ For more information on the UN's work to protect human rights see 'Protect Human Rights', United Nations, available at: www.un.org/en/sections/what-we-do/protect-human-rights.

${ }^{142}$ See among others G. Zyberi, 'The Role and Contribution of International Courts in Furthering Peace as an Essential Community Interest', in C. M. Bailliet and K. Mujezinović Larsen (eds.), Promoting Peace Through International Law (Oxford: Oxford University Press, 2015), pp. 344-67.

${ }^{143}$ Case Concerning Military and Paramilitary Activities in and against Nicaragua (Nicaragua v. United States of America), ICJ Reports (1986) 14, para. 268.

${ }^{144}$ Ibid., para. 291.
} 
fulfil the main purposes of the UN. The Court stated that 'financial obligations which, in accordance with the clear and reiterated authority of both the Security Council and the General Assembly, the Secretary-General incurred on behalf of the United Nations, constitute obligations of the Organization for which the General Assembly was entitled to make provision under the authority of Article $17,{ }^{145}$ These findings have allowed the UN to expand its peacekeeping operations in many parts of the world. ${ }^{146}$ Currently, there are 14 such peacekeeping operations, authorised by the Security Council under Chapter VII of the UN Charter.

The Court has addressed the respective roles of the General Assembly and the Security Council concerning matters of international peace and security. In interpreting this relationship, the Court has 'noted that there has been an increasing tendency over time for [them] to deal in parallel with the same matter concerning the maintenance of international peace and security' ${ }^{147}$ It has further 'observed that it is often the case that, while the Security Council has tended to focus on the aspects of such matters related to international peace and security, the General Assembly has taken a broader view, considering also their humanitarian, social and economic aspects'. ${ }^{148}$ This interpretation conforms to the powers with which the General Assembly and the Security Council are vested under the UN Charter and the subsequent practice of these organs.

\subsubsection{Necessary Protection for UN Human Rights Rapporteurs}

Three cases are relevant when it comes to the protection of UN human rights special rapporteurs. The first one is of a more general nature and concerns reparations for injuries suffered while in the service of the UN. ${ }^{149}$ In the other two cases, namely the Mazilu ${ }^{150}$ and the Cumaraswamy, ${ }^{151}$ the Court has confirmed the immunity from legal proceedings of UN special rapporteurs.

In the Reparation for Injuries advisory opinion the Court found:

[I]n the event of an agent of the United Nations in the performance of his duties suffering injury in circumstances involving the responsibility of a Member State, the United Nations as an Organization has the capacity to bring an international claim against the responsible de jure or de facto government with a view to obtaining the reparation due in respect of the damage caused to the United Nations. ${ }^{152}$

The Court found that the UN would also be able to bring such claims against a non-UN member State. ${ }^{153}$ Moreover, such claims could also be brought for 'obtaining the reparation due in respect of the damage caused to the victim or to persons entitled through him' or her. ${ }^{154}$

\footnotetext{
${ }^{145}$ Certain Expenses of the United Nations (Article 17, Paragraph 2, of the Charter), ICJ Reports (1962) $151,177$. 146 For more information on these missions see 'United Nations Peacekeeping', available at: https://peacekeeping.un.org/en.

${ }^{147}$ Accordance with International Law of the Unilateral Declaration of Independence in Respect of Kosovo, ICJ Reports (2010) 403, para. 41.

148 Ibid.

${ }^{149}$ Reparation for Injuries Suffered in the Service of the United Nations, ICJ Reports (1949) 174.

${ }^{150}$ Applicability of Article VI, Section 22, of the Convention on the Privileges and Immunities of the United Nations, ICJ Reports (1989) 177 (Mazilu).

${ }^{151}$ Cumaraswamy.

${ }^{152}$ Reparation for Injuries, 187.

${ }^{153}$ Ibid.

154 Ibid.
} 
In the Mazilu case, the Court interpreted Section 22 of the Convention on the Privileges and Immunities of the United Nations ${ }^{155}$ as being applicable to persons (other than UN officials) to whom a mission had been entrusted by the Organisation and who were therefore entitled to enjoy the privileges and immunities provided for in that Section with a view to the independent exercise of their functions; that during the whole period of such missions, experts enjoyed these functional privileges and immunities whether or not they travelled; and that those privileges and immunities might be invoked against the State of nationality or of residence unless a reservation to Section 22 of the Convention had been validly made by that State. ${ }^{156}$ In the Cumaraswamy case, the Court found that Section 22(b) of the Convention 'explicitly states that experts on mission shall be accorded immunity from legal process of every kind in respect of words spoken or written and acts done by them in the course of the performance of their mission' ${ }^{157}$ At the same time, the Court pointed out 'that the question of immunity from legal process is distinct from the issue of compensation for any damages incurred as a result of acts performed by the United Nations or by its agents acting in their official capacity'. ${ }^{158}$ The Court also sounded a note of caution by recalling 'that all agents of the United Nations, in whatever official capacity they act, must take care not to exceed the scope of their functions, and should so comport themselves as to avoid claims against the United Nations'. ${ }^{159}$ Through these advisory opinions the Court has clarified the issue of reparation for injuries suffered while serving the UN, as well as the scope of legal protection accruing to UN human rights special rapporteurs under the Convention on the Privileges and Immunities of the United Nations.

\section{Concluding Remarks}

This chapter has shown that through its case law the ICJ has interpreted and developed certain important issues for the understanding and enforcement of human rights within a State's own territorial jurisdiction, as well as extraterritorially. The contribution of the Court, incremental as it is, comes both through its contentious and its advisory jurisdiction. As Simma has noted, 'the Court is singularly capable of devising solutions to practical, more technical, legal problems which arise at the interface between human rights and more traditional international law, thus paving the way for the acceptance of human rights arguments and, more generally, supporting and developing the framework of human rights protection'. ${ }^{160}$ However, the jurisdictional gaps and institutional limitations mean that the ICJ will not always be available for the adjudication of serious human rights violations. Moreover, the cases of Western Sahara and the Wall show the limitations to the Court's potential impact on the enforcement of fundamental human rights vis-à-vis recalcitrant States.

The Court's case law is important for laying down standards of conduct for States, international organisations, other legal entities and even individuals. From a general perspective, as Rodley has noted, the Court's jurisprudence has made clear that 'fundamental human rights must under general international law be respected'. ${ }^{161}$ More recently, Simma has pointed out that the Court has mainstreamed human rights within the larger body of public

\footnotetext{
${ }^{155}$ Convention on the Privileges and Immunities of the United Nations, New York, 13 February 1946, in force 17 September 1946, 1 UNTS 15, Section 22.

${ }^{156}$ For the overview provided on the Court's webpage see 'Applicability of Article VI, Section 22, of the Convention on the Privileges and Immunities of the United Nations', available at: www.icj-cij.org/en/case/81.

157 Cumaraswamy, para. 63.

158 Ibid., para. 66.

${ }^{159} \mathrm{Ibid}$.

${ }^{160}$ Simma 'Community Interest Coming to Life', p. 324.

${ }^{161}$ Rodley, 'Human Rights and Humanitarian Intervention', 333.
} 
international law. ${ }^{162}$ Some of the main areas of contribution of the ICJ to the substantial and procedural aspects of human rights include the prohibition of genocide with the related duties of prevention, investigation and prosecution, and cooperation with international courts; the prohibition of torture, and the related duty to prosecute or extradite; the prohibition of slavery and of racial discrimination. Notably, the Court has recognised the jus cogens character of the prohibition of genocide and of torture. The Court has used the general principle of elementary considerations of humanity to establish a minimum level of protection for individuals in armed conflict situations. The Court has also found that conduct by a State that violates the fundamental rights of individuals is contrary to the principles of the UN Charter, grounding human rights protection in this important international treaty. ${ }^{163}$ Part of the Court's contribution to enhancing the scope of international legal protection accruing to individual persons is also the explanation of the relationship between human rights and humanitarian law. The Court has found that the protection afforded to individuals under international human rights instruments does not cease in situations of armed conflict, except for derogations of the kind to be found under Article 4 of the ICCPR.

The ICJ is an international court of general jurisdiction, widely perceived as the judicial guardian of general international law. The strong tendency of the Court to adhere closely to previous holdings, ${ }^{164}$ ensures stability and predictability. That said, a problematic position when it comes to the enforcement of State obligations concerning the prohibition of genocide through international adjudication is to allow reservations to the ICJ's jurisdiction under Article IX of the Genocide Convention. A potential solution could be that such a treaty reservation is set aside when the Court represents the only venue of international adjudication of alleged serious violations of human rights. From an enforcement perspective, as noted by Wilde, '[m]aking general determinations which have the potential to be followed in any individual case where the same legal principles come to be applied by specialist bodies is a significant, not limited, function [of the Court]'. ${ }^{165}$ Hence, even if its jurisdictional scope remains limited and its advisory function underutilised, the Court's main legal findings can have positive ripple effects for the enforcement of international human rights obligations and the domestication of international human rights standards.

\footnotetext{
162 B. Simma, 'Mainstreaming Human Rights: The Contribution of the International Court of Justice', Journal of International Dispute Settlement, 3 (2012), 7-29.

163 South Africa in Namibia, para. 131.

${ }^{164}$ M. Shahabuddeen, Precedent in the World Court (Cambridge: Cambridge University Press, 1996), p. 238.

165 Wilde, 'Human Rights', 677.
} 